\begin{abstract}
Iranica
Abstracta Iranica Revue bibliographique pour le domaine irano-aryen

Volume 37-38-39 | 2018

Comptes rendus des publications de 2014-2016
\end{abstract}

\title{
Paul F. Jacobs. Lahav IV. The figurines of Tell Halif
}

\section{Astrid Nunn}

\section{OpenEdition}

\section{Journals}

Édition électronique

URL : http://journals.openedition.org/abstractairanica/44246

DOI : 10.4000/abstractairanica.44246

ISBN : 1961-960X

ISSN : 1961-960X

Éditeur :

CNRS (UMR 7528 Mondes iraniens et indiens), Éditions de l'IFRI

Référence électronique

Astrid Nunn, "Paul F. Jacobs. Lahav IV. The figurines of Tell Halif », Abstracta Iranica [En ligne], Volume 37-38-39 | 2018, document 35, mis en ligne le 30 décembre 2018, consulté le 28 septembre 2020. URL : http://journals.openedition.org/abstractairanica/44246 ; DOI : https://doi.org/10.4000/ abstractairanica. 44246

Ce document a été généré automatiquement le 28 septembre 2020

Tous droits réservés 


\title{
Paul F. Jacobs. Lahav IV. The figurines of Tell Halif
}

\author{
Astrid Nunn
}

\section{RÉFÉRENCE}

Paul F. Jacobs. Lahav IV. The figurines of Tell Halif. [Reports of the Lahav Research Project. Excavations at Tell Halif, Israel, vol. IV], Eisenbrauns, 2015, 88 p. et CD

1784 terres cuites, bien conservées ou fragmentaires, d'époque achéménide et hellénistique furent découvertes entre 1992 et 1999. Elles n'ont pas été retrouvées in situ mais soit en surface, soit rassemblées dans des favissae (dépôts) et des fosses du Field IV de la Phase III (Stratum III) romaine tardive et byzantine. Ceci explique que ces terres cuites s'étalent sur une longue période de 850 à 100 av. J.-C. P. Jacobs fait remonter 152 figurines aux VI ${ }^{\text {ème }}$, $V^{\text {ème }}$ et IV ${ }^{\text {ème }}$ s. av. J.-C. (p. 10). Le type le plus fréquent est celui du cavalier (p. 66-67). L'assemblage stylistiquement le plus proche provient de Maresha. L'A. applique les critères développés par A. Erlich pour pouvoir différencier les cavaliers perses et hellénistiques (cf. A. Erlich, «The Persian Period Terracotta Figurines from Maresha in Idumea: Local and Regional Aspects », Transeuphratène 32, 2006, pp. 45-59).

\section{AUTEURS}

\section{ASTRID NUNN}

Université de Munich 